\title{
Economic Depression and the Silver Question in Nineteenth-Century China
}

\author{
Richard von Glabn
}

The last decade of the eighteenth century marked a crucial transition in China's economic fortunes. After a century of steady growth in production, population and prosperity that had begun in the 1680s, a sudden reversal occurred in the 1790s. Prices tumbled amid widespread reports of economic distress and deteriorating trade. The White Lotus Rebellion (1796-1805) devastated a large swath of western China, forcing the Qing imperial government to empty its treasuries in costly military campaigns. The final suppression of the rebellion brought some respite, but not a return to prosperity. In 1815, the eruption of the Tambora volcano in Indonesia - the largest volcanic eruption in recorded history-triggered several years of global climatic disturbances, drastically disrupting agriculture as far away as New England and Ireland. Catastrophic flooding in the 1820s-including the devastating Yellow River floods of 1824-1826-precipitated famines in both northern and southern China, fomenting peasant unrest and urban food riots. The deflationary spiral triggered in the 1810 s intensified in subsequent decades. The worst years

R. von Glahn $(\bowtie)$

University of California, Los Angeles, USA

(C) The Author(s) 2018

M. Perez Garcia and L. de Sousa (eds.), Global History and New

Polycentric Approaches, Palgrave Studies in Comparative Global History, https://doi.org/10.1007/978-981-10-4053-5_5 
coincided with the reign of the Daoguang Emperor (r. 1820-1850), and thus this era has become known as the Daoguang Depression.

The Daoguang Depression also coincided with the two most traumatic events in the history of nineteenth-century China: the Opium War fiasco (1839-1842) and the onset of the Taiping Rebellion (1850-1864). The immediate economic effects of the Qing's ignominious defeat in the Opium War were minor compared to the cost to the imperial court's prestige. The Taiping Rebellion, in contrast, left much of the central and lower Yangzi River basins-the economic heartland of China-in ruins. Estimates of the loss of life over the course of the rebellion range from $\mathbf{2 0 - 5 0}$ million to as many as 90 million people. The Taiping Rebellion abruptly ended the long surge that had increased China's population from roughly 150 million in 1680 to an estimated 436 million in 1850, a level that would not be reached again until the 1920s. These events transformed the image of China in Western eyes, indelibly branding it as a poor and backward country just at the moment that the West began to enjoy the first fruits of the self-sustaining economic growth that accompanied the Industrial Revolution.

The stark contrast between the 'prosperous age' (as contemporaries themselves described it) of the eighteenth century and the dramatic regression of the nineteenth century raises important questions about the nature of the pre-modern Chinese economy. Recent scholarship seeking to frame the economic torpor of nineteenth-century China in a long-term perspective has proposed three principal explanations: (1) neo-Malthusian models that emphasize the distinctive features of China's 'peasant economy'; (2) dependency theoriesrooted in the older 'imperialism of free trade' paradigm-that assert the deleterious consequences of China's growing integration into a global trade system; and (3) a neo-Smithian perspective that underscores the ecological limits to economic growth and the diminishing returns to market expansion found in all pre-modern agrarian societies (not just China).

Neo-Malthusian models provide structural explanations for the inherent limits of the small-farm peasant economy that has prevailed in China for most of its imperial history, and certainly throughout the late imperial era. Kang Chao has postulated that the continuous fragmentation of landholdings under China's equal inheritance laws 
and the worsening labour/land ratio that accompanied unrestrained population growth resulted in steadily decreasing returns to agricultural work. Philip Huang's 'involution' thesis likewise emphasizes that the rationality of peasant self-sufficiency and strategies of household reproduction favoured a labour-intensive mode of production rather than capital-intensive managerial farming. Ironically, the expansion of markets in the late imperial era provided enhanced opportunities for family survival through production for the market, but at the cost of diminished labour productivity that stifled wage-based and capitalintensive forms of economic organization. Both Chao and Huang agree that labour productivity in Chinese agriculture had peaked in the Song dynasty and diminished steadily afterwards (Chao 1988; Huang 1990).

In the eyes of dependency theorists, the emergence of a world economy since 1500 resulted in the incorporation of the non-European world into a capitalist system dominated by European nations. Commodity flows and capital investment forged links that fostered the economic subordination of peripheral satellite regions to the hegemonic powers of the capitalist core. The sociologist Frances Moulder, a student of Immanuel Wallerstein, was among the first to apply this analysis to China (Moulder 1977: 91-127). In her view, China's economic incorporation into the world capitalist system began in around 1800, although it intensified after the Opium War, which marked the beginning of China's political incorporation. In a different vein (quite distinct from Wallerstein's world-systems analysis), William Atwell has argued that China had already become economically dependent on the global trading system in the seventeenth century. According to Atwell, the growth of domestic commerce in the late Ming period, which was fuelled by massive imports of foreign silver, rendered the Chinese economy vulnerable to disruptions in global trade. The abrupt decline in European overseas trade in the middle decades of the seventeenth century drastically reduced the flow of silver to China, wreaking economic turmoil that contributed directly to the collapse of the Ming state and the Manchu conquest of China in 1644 (Atwell 1986, 2006). Manhoung Lin claims that the Chinese economy in the nineteenth century likewise was dependent on the global trading system, and especially imports of foreign silver, to sustain its prosperity. The combination of economic depression in Europe-resulting in the evaporation of demand 
for Chinese tea and silks - and a crisis in worldwide silver production not only halted the flow of silver to China, but also reversed that flow. In her view, this haemorrhage of silver was the principal cause of the Daoguang Depression (Lin 2006).

Both Huang's neo-Malthusian 'involution' thesis and the dependency models express the idea that rather than improving economic welfare, market integration acted as a catalyst for the immiseration of the Chinese populace. A much more positive view of the role of the market in China's late imperial economy has been advanced by the so-called 'California School' of revisionist economic history. ${ }^{1}$ From this perspective, similar Smithian dynamics of market expansion and specialization of labour animated economic growth in the main regions of advanced economic development across the world in the early modern era, including the Jiangnan region of China, the Kantō Plain in Japan, Bengal, and the leading European economic regions of England and the Low Countries. However, as Smith himself had prophesied, given the limitations of pre-modern technology in what remained fundamentally agrarian economies, by the end of the eighteenth century, all of these regions had begun to encounter diminishing returns to labour and capital investment. Ecological constraints-maximal exploitation of arable land, deforestation and the growing ecological costs of intensive land useinhibited further economic improvement. Only through a revolution in energy production-the invention of steam-powered mechanization utilizing fossil fuels in place of human and animal labour and inefficient water and wind power-could liberation from the 'biological old regime' be achieved. By the turn of the nineteenth century, just such a great leap forward in energy production was well under way in Britain, paving the way for the Industrial Revolution. In China and other advanced economic regions, however, the productive potential of traditional technologies had already been exhausted, impeding further economic development (Pomeranz 2000; Marks 2002). Hence, a 'Great Divergence' emerged between England's path to self-sustaining economic growth and the 'high-level equilibrium' of pre-modern economies elsewhere.

This chapter will examine evidence for population, prices, wages and income, standards of living, silver flows and money supply in China during the first half of the nineteenth century in order to elucidate the causes and consequences of the Daoguang Depression. The findings present here do not support the neo-Malthusian and dependency 
hypotheses outlined above. Instead, the neo-Smithian analysis of the California School provides the most satisfactory explanatory model for the economic distress China suffered in this period. In addition, the Daoguang Depression should be seen as part of a long-term pattern of cyclical conjunctures of economic expansion and contraction that had determined the basic rhythm of economic life not only in late imperial China, but in early modern Europe as well.

\section{Measuring Economic Performance: GDP AND ReAL Wages}

Economic historians have responded to Kenneth Pomeranz's bold assertion that income levels in eighteenth-century Jiangnan were on a par with the most advanced economic regions of Europe (England and the Netherlands) by making a concerted effort to develop quantitative measures to compare the economic performance of late imperial China with other advanced economies in Europe and Asia. The two principal measures currently utilized in making such comparisons have been estimates of Gross Domestic Product (GDP) and real wage rates. To be sure, there are significant empirical challenges to calculating GDP and real wages as well as theoretical problems regarding their utility as measures of comparison, and the results of such exercises must be viewed with caution. ${ }^{2}$

The late Angus Maddison was the pioneer in developing GDP estimates to measure and compare long-term economic performance on a global scale. Maddison estimated that China's per capita GDP had reached a high level (\$600 in 1990 international dollars) in 1700slightly less than two-thirds of the level of Europe, but ahead of both Japan and India. Maddison also asserted that aggregate GDP growth in China outpaced Europe between 1700 and 1820, with the result that in 1820 China's share of global GDP reached 33\%, eclipsing that of Europe $(27 \%)$. But this increase resulted from China's huge population expansion, not economic development; on a per capita basis, China's GDP had stagnated since 1700, in contrast to sustained improvement in Europe. By Maddison's calculation, China's per capita GDP in 1820 had sunk to only $55 \%$ of the European level (Maddison 2001: 42-48, 2007, 44, Tables 2.1-2.2c).

Most efforts to quantify the size of the economy in late imperial China have been responses to Maddison's methods and results. 
Maddison's technique, it should be noted, was relatively crude and presumed that per capita output remained unchanged from the end of the Song dynasty to the nineteenth century (Table 1). William Liu has derived his estimates - which show a very high per capita GDP in the Song that fell precipitously in the Ming and only partially recovered in the Qing-from calculations of soldiers' real wages as a proxy for per capita income. However, there are substantial problems with Liu's methodology, and his estimates of GDP cannot be considered reliable. ${ }^{3}$ Liu $\mathrm{Ti}$, who was among the first scholars to utilize national accounting analysis, has arrived at strikingly different results. He argues that agriculture generated a mere $54 \%$ of GDP in 1600 , in contrast to $34 \%$ produced by industry and construction, and thus his estimates of Ming GDP are far higher than those of William Liu. By Liu Ti's calculations, nominal GDP grew fivefold between 1600 and 1840, but the increase in real terms (constant prices) was far more modest, and per capita real GDP declined by roughly $20 \%$ over that period. Part of this decline can be explained by the reduced share of the industrial sector, which in Liu's analysis declined by nearly half, to $20 \%$ of total GDP, by 1840 (agriculture, in contrast, rose to 69\%). The size of the service sector remained constant (around $11-12 \%$ of the total), but its composition changed radically: Liu Ti suggests that finance comprised a third of the service sector in $1840 \mathrm{com}$ pared to only $4 \%$ in 1600 , while the government spending's share of the service economy fell from 45 to $22 \%$ (Liu 2009).

A recent analysis by Stephen Broadberry and his collaborators concurs with William Liu's view that per capita GDP peaked in the Northern Song, but then declined continuously thereafter. The Broadberry team's figures indicate a steady equilibrium throughout the Ming period at the same level as the Northern Song, followed by a steep plunge in the Qing period. By their calculations, population growth had sharply curtailed per capita GDP already by 1750, with a further decline by 1850 to a level roughly $60 \%$ that of the Song peak. These findings largely reflect the failure of grain yields to keep pace with population growth from the Song period onwards and thus echo Kang Chao's analysis (Broadberry et al. 2017). ${ }^{4}$ Shi Zhihong and his collaborators arrive at slightly lower (by roughly 10\%) per capita GDP figures from 1661 to 1850 than Broadberry et al., but the trend they chart is virtually identical. The key new argument proposed by the Shi Zhihong group is that the decline in per capita GDP largely resulted from the relative decline in 


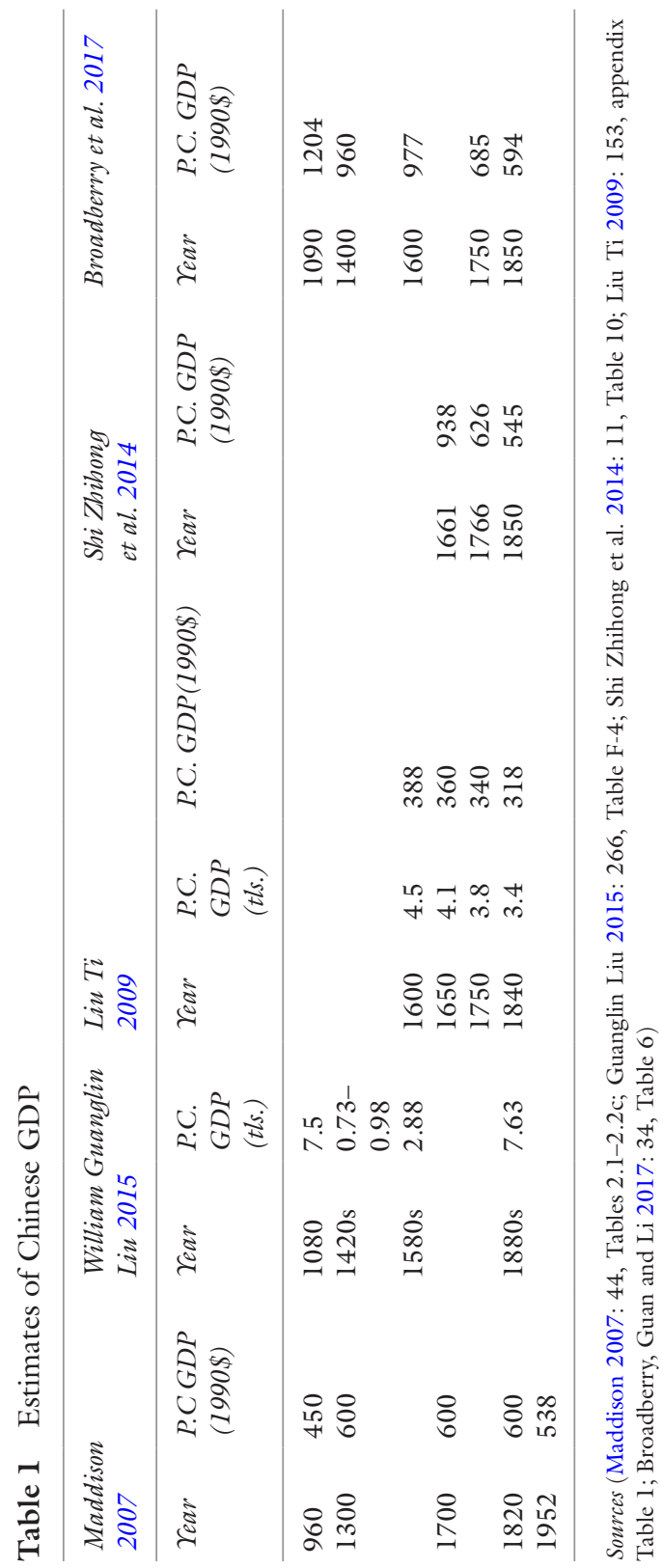


the high-income service sector (especially the government) from 1650 to 1900 (Shi et al. 2014: 6-7).

Thus, recent efforts to calculate GDP for the Ming and Qing periods have produced divergent results, largely because of different premises about the relative weights of agriculture, industry and services in the Chinese economy. Most of these scholars agree, however, that the surge in population growth during the Qing period steadily reduced per capita GDP. There is also general agreement that Chinese per capita GDP was already far lower than the levels of England and the Netherlands in 1600, and fell even further behind by 1800. Shi Zhihong et al., for example, estimate that China's per capita GDP in 1812 was a mere $28 \%$ of that of England (Shi et al. 2014: 11, Tables 10-11). ${ }^{5}$ Although Liu Ti diverges from others in portraying China's per capita GDP as roughly constant during the Qing dynasty, he concludes that it had declined to less than $20 \%$ of the British level by 1840 . Liu Ti's absolute figures for Chinese per capita GDP are surely too low, but his analysis of the composition of GDP and the long-term trend in per capita GDP seem more plausible.

Given the severe limitations of the data and the necessity of making very large and tentative assumptions, these efforts to analyse the size and structure of GDP in pre-modern China can only be regarded as heuristic exercises. Of course, as Pomeranz has persuasively argued, comparing the whole Chinese Empire, with its vast disparities in economic development, to European countries such as Britain mixes together highly dissimilar and unequal units of analysis. Instead, Pomeranz has insisted on the necessity of comparing the most advanced economic regions of roughly equal size, such as England, the Netherlands, Jiangnan and the Kantō Plain in Japan. This principle is the cornerstone of the collaborative study by Li Bozhong and Jan Luiten van Zanden, which compares GDP and labour productivity in the Netherlands and two counties (Huating and Lou) in Songjiang prefecture (near Shanghai) in the 1820s (Li and Van Zanden 2012). ${ }^{6}$ The geography of the two regions is similar (low-lying plains with ready access to both inland and overseas water transport), and they both were characterized by high rates of urbanization and commercialization ( $\mathrm{Li}$ estimated that $80 \%$ of output and $67 \%$ of consumption in Hua-Lou passed through the marketplace). But the regional economies differed in significant ways: Hua-Lou, the heart of the Jiangnan cotton industry, had a much higher proportion of the 
workforce engaged in manufacturing, whereas commerce and banking employed a much greater share of the Dutch population. Li and van Zanden find that labour productivity in agriculture was very high in both regions, but wages from artisanal and industrial work in Hua-Lou were far lower than in the Netherlands, reflecting the fact that Hua-Lou's industrial workforce consisted overwhelmingly of women spinners and weavers. Consequently, there was a large disparity in per capita income between the two regions: the Dutch level was 81 per cent higher $(86 \%$ higher when measured in purchasing power parity (PPP) terms) than in Hua-Lou. The authors attribute this gap to greater Dutch capital investment in labour-saving technologies in industrial production, transport and to some extent agriculture. Low wage rates and high interest rates and capital costs acted as brakes on such investment in Hua-Lou. Li and van Zanden calculate that Hua-Lou's per capita GDP in 1820 was $\$ 988$, or about $83 \%$ of the level of Western Europe as a whole, but only $54 \%$ of that of the Netherlands. In contrast to Pomeranz and studies that have focused on consumption, $\mathrm{Li}$ and van Zanden find a large gap in GDP between Jiangnan and the advanced economic regions in Europe. But $\mathrm{Li}$ and van Zanden's estimate for Hua-Lou's per capita GDP is 70-80\% higher than the estimates of Broadberry et al. (\$598) and Shi Zhihong et al. $(\$ 545)$ for China as a whole in $1850 .^{7}$

Economic historians commonly utilize real wages as an index of the standard of living, based on the logic that since wage earners occupied a marginal niche within pre-modern economies, their wages can serve as a proxy for marginal labour productivity in general. Robert Allen's comparison of real wages in China and Europe has found that wage rates in Ming-Qing China were substantially lower than in England and the Netherlands, although comparable to other parts of Europe such as Germany and Italy (Allen 2009). Drawing primarily on Li Bozhong's data (with adjustments) and converting income data to PPP exchange rates, Allen concluded that the labour productivity of Jiangnan farmers was already high in 1600 and remained unchanged in 1800 at a level comparable to the richest agricultural regions in England. Farm work was vastly more intensive in Jiangnan: labour intensity (days worked per unit of land) was eight times greater in Jiangnan than England, but output in Jiangnan was nine times higher. In the early seventeenth century, Jiangnan's farming families earned substantially higher incomes than English farm workers. But the net income (measured in rice) of female 
textile workers fell by half between the seventeenth and nineteenth centuries. By Allen's calculations, family income in Jiangnan declined by $42 \%$ from 1620 to 1820 , largely due to falling prices for textiles and the sharp reduction in farm size. To be sure, the income of Jiangnan farm families c. 1820 was no worse than that of English farm workers. But Allen concludes that population growth and the worsening land/labour ratio had resulted in growing impoverishment even in Jiangnan. ${ }^{8}$

In another study, Allen and a group of collaborators have sought to compare the real wages of unskilled workers in Beijing, Suzhou and Guangdong with other European and Asian cities (Allen et al. 2011). They conclude that real wages in Chinese cities were already far below (barely half) the level of London and Amsterdam in the first half of the eighteenth century, although on a par with Central and Southern European cities well into the nineteenth century. But the utility of such comparisons is questionable. Compared to Europe, a far smaller percentage of the Jiangnan workforce consisted of full-time wage labourers-perhaps 10-15\%, in contrast to more than half in England and the Netherlands. Wage labourers in Jiangnan earned only $30-40 \%$ of the income of tenant farmers with security of tenure, and even less compared to smallholders (Pomeranz 2008: 84-85; Xu and Wu 2000: 37). ${ }^{9}$ The earnings of such wage labourers - the vast majority of whom were single men-barely sufficed for their own upkeep and could not support a family. The disparity in proletarian wages adduced by Allen and his collaborators is not incompatible with closer parity in family incomes and living standards in general.

Nonetheless, recent efforts to quantify economic performance in Ming-Qing China suggest that per capita output declined steadily from 1600 to 1810 - with the most precipitous fall occurring during the eighteenth century - and then stabilizing (at a very low level) that persisted until the 1940s (Liu Ti suggests that this plateau was reached earlier in around 1770). These studies thus portray Qing China as caught in the Malthusian scissors of rising population growth exceeding productive capacity. There is considerable evidence that the Chinese economy had begun to exhaust its productive capacities by 1800 . But whether the depression of the early nineteenth century was driven by Malthusian factors requires further investigation. 


\section{Population, Prices and Money Supply}

Between the pacification of Taiwan in 1683 and the outbreak of the White Lotus Rebellion in 1796, China enjoyed a century of remarkable domestic tranquility that fostered unprecedented population growth. By the end of the seventeenth century, China's population had returned to its Ming peak of 150 million. Over the course of the eighteenth century, the empire's population doubled, with the most pronounced increase occurring during the first half of the eighteenth century (Table 2). While economic growth in the late Ming period had been concentrated in the southeastern coastal provinces, during the early and middle Qing period, the most striking increases in population and agricultural production were found in the interior provinces of the south (Hunan, Hubei and especially Sichuan), the Central Plain and the southwestern frontier provinces. Much of this increase resulted from the advance of Chinese settlement and agriculture into the remote upland regions of the interior. As Fig. 1 shows, between 1776 and 1820, the rate of increase was significantly higher in the sparsely inhabited provinces in the west (Sichuan and Shaanxi above all).

Contemporary observers fully recognized this remarkable population increase, and as early as 1748 leading statesmen expressed fears that population growth - which had always been seen as a sign of good governance-was outstripping food production, creating a disequilibrium that drove up prices and posed an endemic threat to subsistence and survival (Will 1994: 866-868; Marks and Chen 1995: 141-142; Dunstan 2005: 307-462). Certainly, the eighteenth century was also marked by a secular rise in the price level. The sharpest increases occurred in rice-deficit areas such as Jiangnan and Guangdong in 1730-1758, but prices moderated thereafter, and even fell in the 1790s. ${ }^{10}$ The most comprehensive evidence for price inflation comes from rice prices (Fig. 2), but the prices

Table 2 Population of Qing China

\begin{tabular}{lc}
\hline & $\begin{array}{c}\text { Population } \\
\text { (in millions) }\end{array}$ \\
\hline 1680 & 150 \\
1776 & 311 \\
1820 & 383 \\
1850 & 436 \\
\hline
\end{tabular}

Source Cao Shuji (2000: 704, Table 16-2) 


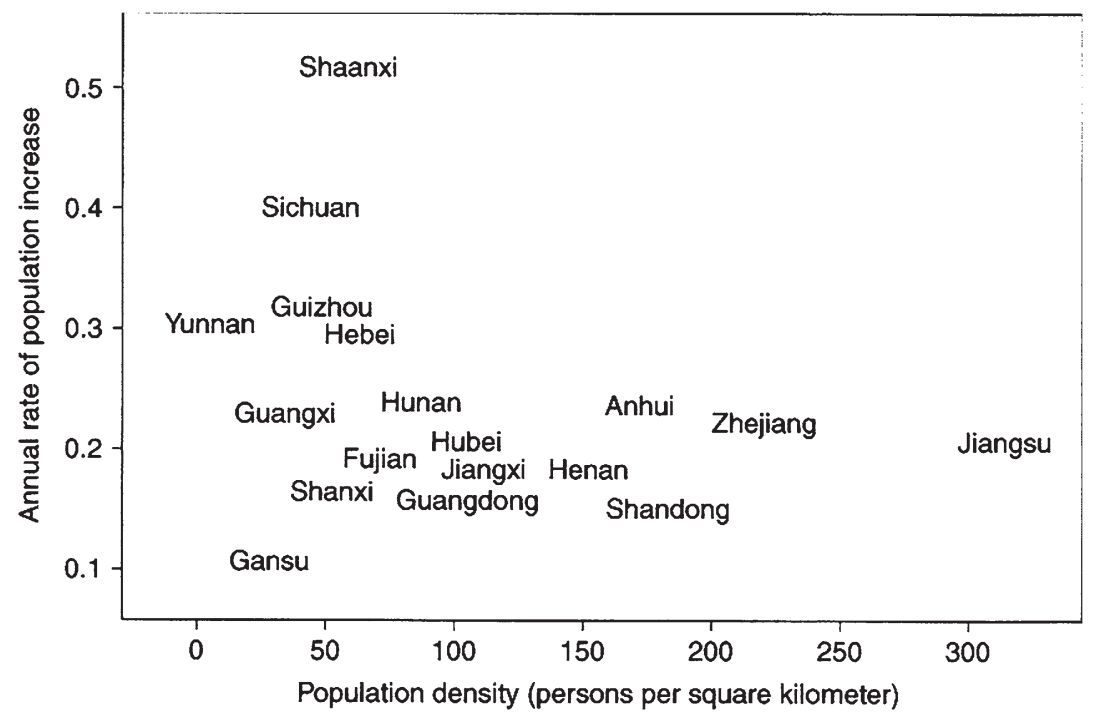

Fig. 1 Population density and rates of growth, 1776-1820. Source Peng Kaixiang (2006: 61, Fig. 5.4)

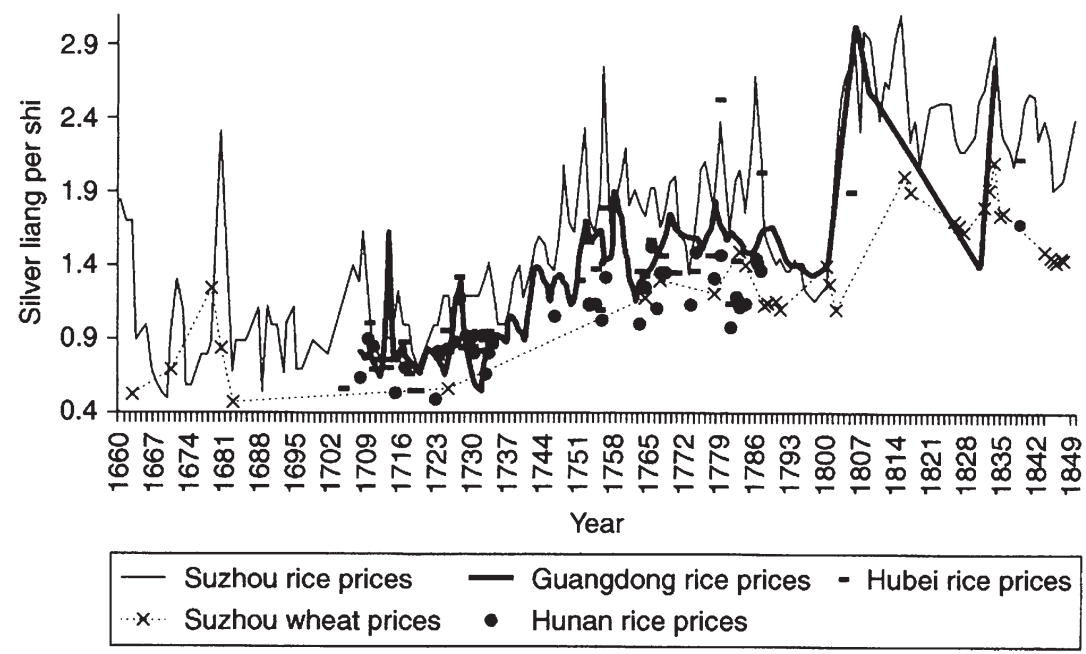

Fig. 2 Grain prices in South China, 1660-1850. Source Peng Kaixiang (2006: 33, Fig. 3.1) 
of other grains, cotton, silk and various consumer goods (clothing, fuel, liquor, medicine and paper) also exhibit similar trends during the eighteenth century (Kishimoto 1997: 138-153; Peng 2006: 34-36; Chen 2005: 158-161). Thus, relative prices remained fairly stable.

Although the strain imposed on the environment and productive resources by population growth became increasingly severe, the evidence does not suggest that China had reached the point of a Malthusian demographic crisis. To be sure, sharp spikes in mortality occurred on a regular basis. In 1813-1814, a severe drought caused grain prices in Hebei to double and culminated in a genuine mortality crisis, with the state powerless to relieve starvation and suffering. Hebei again suffered severe harvest failures in the early 1820s ( $\mathrm{Li}$ 2007: 255-266). Demographic research on rural Liaoning (Manchuria) has demonstrated

\section{5}

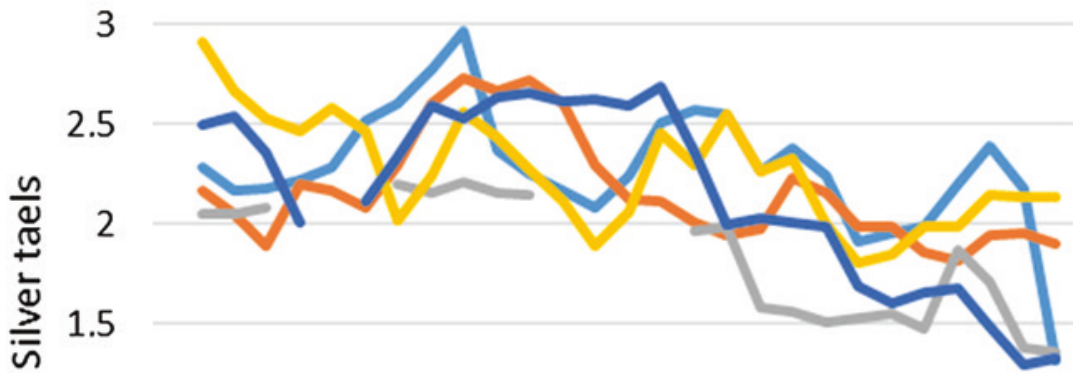

1

0.5

0 $\begin{array}{llllll}1825 & 1830 & 1835 & 1840 & 1845 & 1850\end{array}$

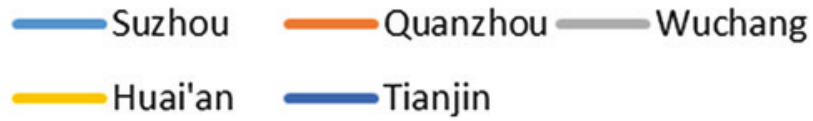

Fig. 3 Rice prices in five major markets, 1826-1852. Source Wang Yeh-chien (1996: 266, Table 3) 
definite correlations between vitality and short-term price movements: marriages and births declined during years of high food prices and increased when prices were low, while conversely deaths rose and fell in tandem with the rise and fall of grain prices. Population growth certainly exacerbated the economic pressure on the poor. Long-term trends in Liaoning show no increase in male mortality during the period 18001850, but household formation, marriages and births declined, suggesting a society under demographic stress (Lee and Campbell 1997: 31-39).

But long-term correlations between prices and population change are less evident. Following the steady increase in grain prices across the eighteenth century, prices plunged in the 1790s and then rose after 1800. Grain prices spiked sharply in both the north and the south in the 1810 s, but abated in most areas in the 1820s. From 1835 to the early 1850 s, grain prices trended downwards in all major commercial regions of China (Fig. 3). ${ }^{11}$ According to the ledgers of the Tongtaisheng, a

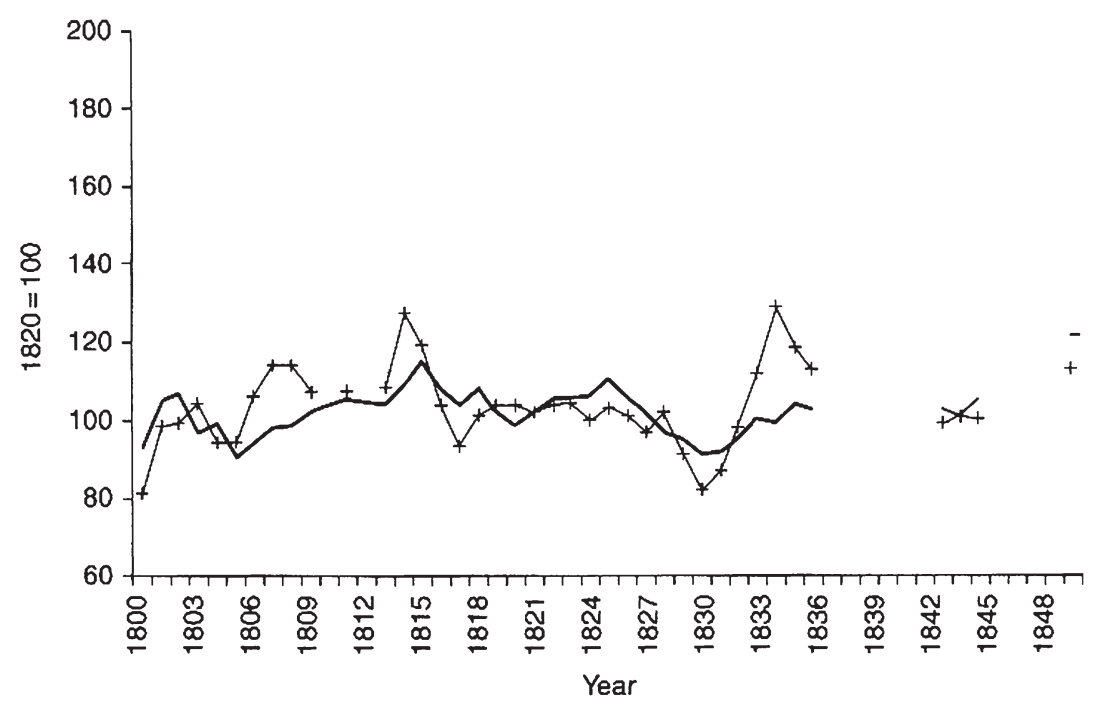

+ Price index of agricultural products - Price index of handicraft products

Fig. 4 Prices of agricultural and manufactured goods in Ningin (Hebei), 1800-1850. Source Ningjin Tongtaisheng ledgers; Peng Kaixiang (2006: 90, Fig. 5.4) 
general goods merchandising firm based in Ningjin, Hebei, the nominal prices of both agricultural and manufactured goods rose in the 1810s and then declined in the 1820s (with a sharp drop in the early 1830s), before returning to their previous level (Fig. 4). But in terms of silver (converted from prices originally recorded in coin), the prices of both agricultural and manufactured products as well as wages decreased steadily from 1815 to 1850 , apart from a brief recovery in the mid-1830s (Fig. 5). Other data corroborate these trends. The welfare ratios for Beijing, Suzhou and Guangzhou wage workers postulated by Allen and his collaborators declined slowly across the eighteenth century, abruptly rose in 1780-1795 and then fell even more sharply in 1795-1820. Subsequently, the welfare ratio in Beijing (the only city for which they have data for the 1820s-1840s) continued to decline (Allen et al. 2011: 27-28, Figs. 5-6). However, when measured in grain rather than silver, wages of unskilled labourers were relatively stable in Beijing during the period 1807-1838. Nominal daily wages paid in coin (the typical

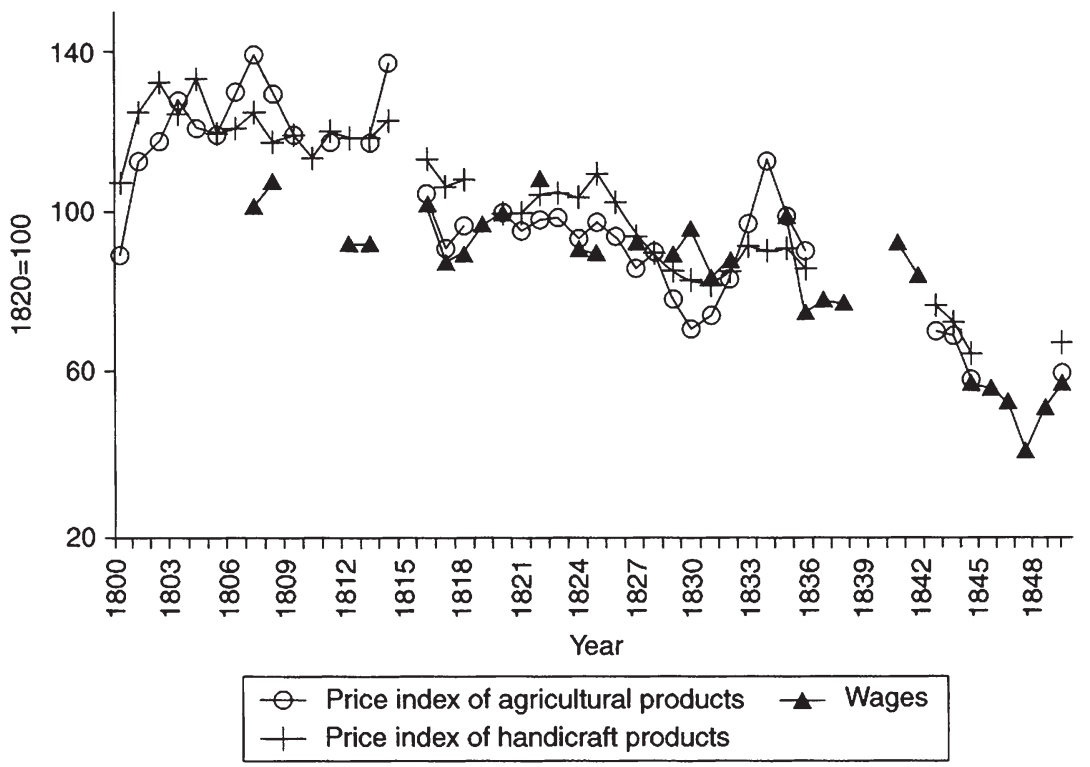

Fig. 5 Prices and wages (Silver equivalents) in Ningjin (Hebei), 1800-1850. Source Ningjin Tongtaisheng ledgers; Peng Kaixiang (2006: 37, Fig. 3.5) 
practice in Beijing) rose slightly during this period, but purchasing power measured in silver fell significantly (Fig. 6). The Daoguang Depression years of 1820-1850 thus witnessed static or declining real prices and wages - and in silver terms, steep deflation-even as China's population continued to grow at a steady rate. These price trends are not consistent with a Malthusian scenario of intensifying pressure on food supply, which should have had inflationary consequences.

It is more likely that the price inflation of the eighteenth century reflected the substantial growth of the money supply rather than the

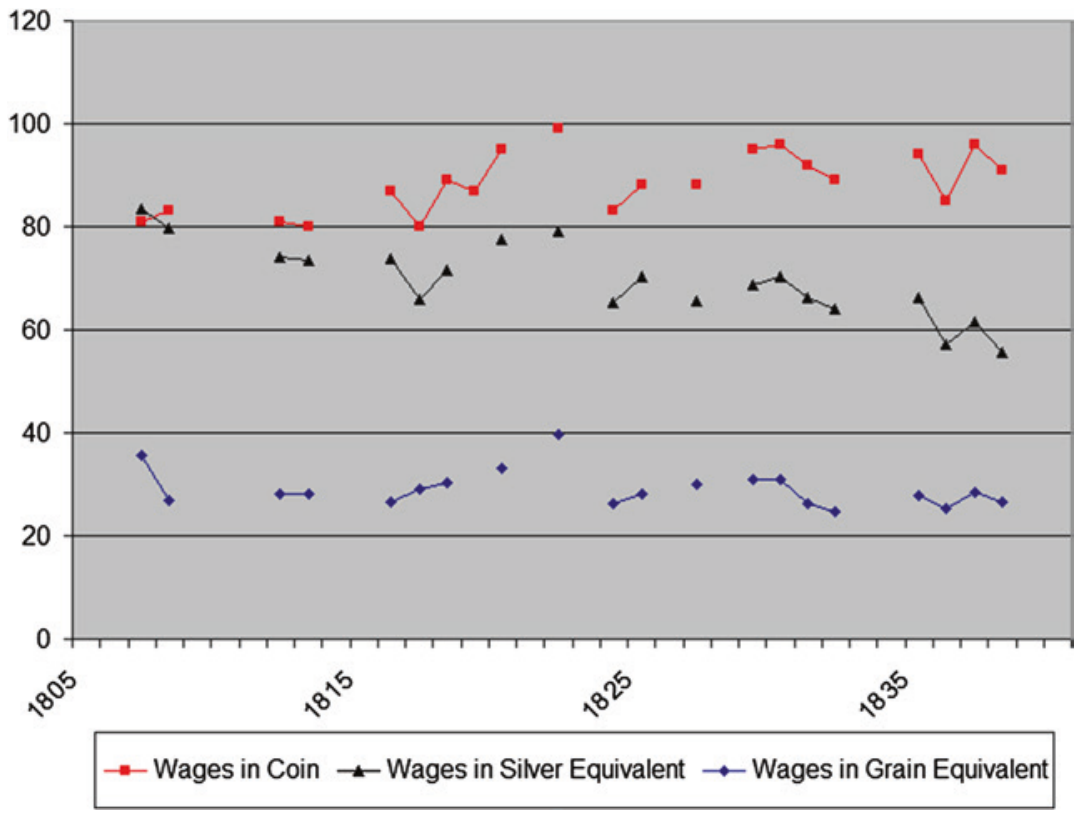

Fig. 6 Daily wages of unskilled labourers in Beijing, 1807-1838. Wages in coin: $w e n /$ day (based on Buck). Wages in silver equivalent: $l i /$ day (based on exchange ratios in Tongtaisheng ledgers). Wages in grain equivalent: shao/day (based on Jiangnan rice prices). Source Li Longsheng (2010: 174, Table 3.17) 
stress of overpopulation. ${ }^{12}$ The keen attention given to China's imports of foreign silver has obscured the fact that the major force driving the growth of the money supply in the eighteenth century was a dramatic increase in the minting of bronze coin. Although silver imports in the early eighteenth century had fallen from their peak level of a century earlier, imports of Japanese copper and the rapid development of copper mining in Yunnan from the 1730s to the 1790s enabled the Qing state to raise the output of state mints nearly tenfold compared to the late seventeenth century. ${ }^{13}$ During the period 1740-1785, the average annual output of bronze coin was equivalent in value to 125 tons of silver at a time when silver imports averaged 50 tons per year (Fig. 7). The demand for bronze coin was most acute in highly commercialized regions such as Jiangnan, where bronze coin displaced silver as the monetary standard

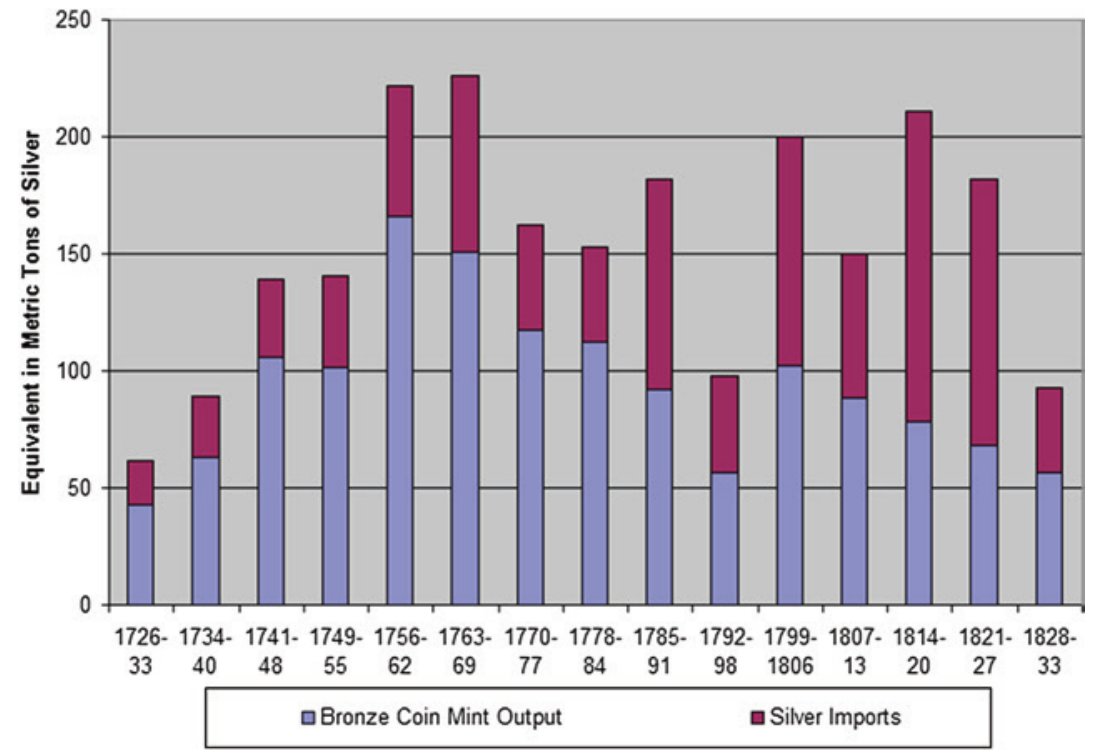

Fig. 7 Growth of the money supply, 1726-1833 (annual averages). Sources Bronze coin mint output: Vogel n.d.: 606-640, Appendix D.4. Silver imports: Dermigny (1964, 2: 735) Coin-silver exchange ratios: Vogel (1987: 17-23, Appendix 3) 


\section{Indices of Silver:Bronze Coin Exchanges Ratios and Bronze Coin Output, 1691-1800}

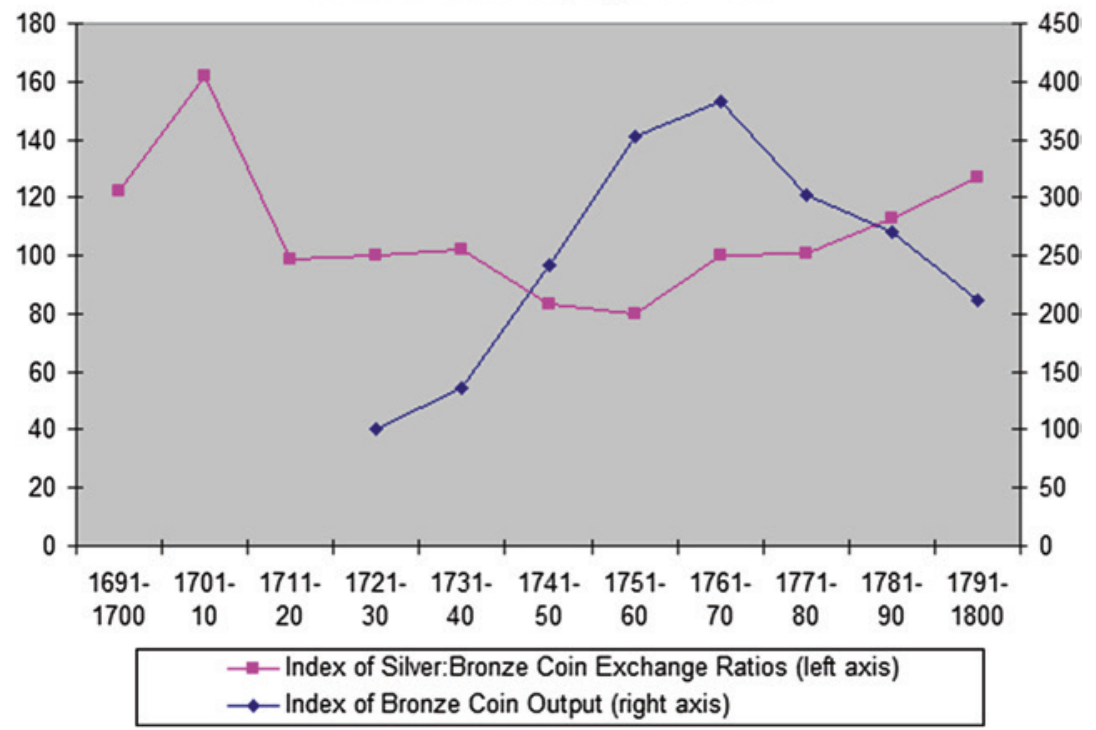

Fig. 8 Silver: Bronze coin exchange ratios and bronze coin output, 16911800. 1721-1730 = 100. Source Hans Ulrich Vogel, 'Chinese Central Monetary Policy and Yunnan Copper Mining, 1644-1800' (unpub. ms.), Vogel n.d.: 414424, Table C. 1, 606-632, Table D4.2

in the mid-eighteenth century. ${ }^{14}$ Significantly, bronze coin rose in value during the middle decades of the century, precisely at the time that the Qing mints reached their peak level of output (Fig. 8)-exactly the opposite of what a crude quantity theory of money would predict. It is also readily apparent that the trends in eighteenth-century silver to bronze coin exchange ratios show no correlation with the fluctuations in imports of foreign silver. The value of silver rose in the last two decades of the eighteenth century even as silver imports surged to new highs.

\section{The Silver Question}

It has been argued that the chief cause of economic depression in the early nineteenth century was the massive outflow of silver during these years, a reversal of the centuries-long pattern of silver flowing into China 
as a result of surging opium imports (Mann Jones and Kuhn 1978: 130; Peng 1983: 25-26). This argument traces back to contemporary Chinese officials and statesmen: as early as 1820 , the influential policy advisor Bao Shichen warned that opium smuggling by foreign merchants was causing 100 million silver taels to drain out of China every year (Rowe 2010, 72). ${ }^{15}$ A large body of modern scholarship likewise has attributed the 'drain of silver' to the dramatic increase in opium imports. Manhoung Lin has modified the standard explanation for the drain of silver, de-emphasizing the effects of the import of opium and instead attributing the outflow of silver to a global crisis in the production of precious metals and a worldwide economic depression that eroded demand for Chinese exports such as tea (Lin 2006). With the revival of gold and silver production and rapid growth of tea and silk exports in the 1850s, silver once again began to flow into China. At the same time, Lin, like earlier scholars, depicts the Chinese economy as having developed an unhealthy dependency on imports of foreign silver that left it vulnerable to the vicissitudes of the global capitalist economy.

Since the pioneering work of Hosea Morse in the early twentieth century, the reversal in the flow of silver has been dated to the late 1820s. However, in her book, Lin Man-houng developed a new quantitative study of China's balance of trade that proposed a new dating for the onset of the reversal in the flow of silver beginning in 1808 (Table 3). According to Lin's calculations, China's net silver exports during the period 1808-1856 amounted to 384 million pesos (10,070 metric tons). But she went on to emphasize that silver began to flow back into China in substantial quantities after 1857 , while imports of opium reached unprecedentedly high levels and accounted for an even greater proportion of

Table 3 Lin Man-houng's estimates of net silver flows in and out of Qing China. Unit: millions of silver pesos

\begin{tabular}{lll}
\hline Years & Net inflow & Net outflow \\
\hline $1721-1740$ & 68 & \\
$1752-1800$ & 105 & 384 \\
$1808-1856$ & & \\
$1857-1866$ & 187 & \\
$1868-1886$ & 504 & \\
\hline
\end{tabular}

Source Lin (2006: 95) 
China's imports. She concluded that the import of opium alone cannot explain the outflow of silver in the first half of the nineteenth century.

Lin's calculation that the net outflow of silver began as early as 1808, rather than from 1826 as indicated by Morse's data, certainly was a startling new finding. However, Kishimoto Mio has drawn attention to errors in Lin's calculations that seriously misrepresent the export of silver from China (Kishimoto 2009: 93-95). Subsequently Lin acknowledged the errors and modified her data, lowering her estimate for the net outflow of silver during the period 1808-1856 from 384 million pesos to 327 million pesos. Most importantly, her revised figures indicate that the reversal in the flow of silver began in the late $1820 \mathrm{~s}$, a re-affirmation of the dating originally proposed by Morse (Lin 2011: 17, Fig. 10). In my view, however, Lin's data is still flawed, because she relies on balance of trade statistics rather than actually measuring the flow of silver. My own estimate of China's silver imports and exports during the period 18181854 (Table 4) indicates that China experienced a net loss of 134 million pesos, or 3576 tons of silver, rather than the 308 million pesos projected by Lin for these years.

Although Lin Man-houng's analysis shifts the focus away from opium, she still views the outflow of silver as the proximate cause of economic depression in China. But I believe this thesis is untenable. ${ }^{16}$ Contrary to Lin's claims, there was no crisis of silver production following the demise of Spanish colonial rule in Latin America in the 1810s. Coin output in Mexico did decline from the historical high of 18 million pesos minted in 1810 , but by 1827, when the outflow of silver from China began,

Table 4 Net flow of silver from China, 1818-1854 (all figures in millions of pesos)

\begin{tabular}{llll}
\hline & $\begin{array}{l}\text { A } \\
\text { Silver imports }\end{array}$ & $\begin{array}{l}\text { S } \\
\text { Silver exports }\end{array}$ & $\begin{array}{l}\text { Net flow of silver } \\
(A-B)\end{array}$ \\
\hline $1818-20$ & 19.31 & 9.42 & +9.89 \\
$1821-25$ & 26.13 & 5.12 & +21.01 \\
$1826-30$ & 12.72 & 25.68 & -12.96 \\
$1831-35$ & 5.17 & 24.98 & -19.81 \\
$1836-40$ & 2.77 & 32.26 & -29.49 \\
$1841-45$ & 2.34 & 53.67 & -51.33 \\
$1846-50$ & 0.24 & 30.82 & -30.57 \\
$1851-54$ & 0.82 & 21.51 & -20.69 \\
Total & 69.51 & 203.46 & -133.95 \\
\hline
\end{tabular}

Source von Glahn (2013: 50, Table 2.10) 
output had returned to a minimum of 10 million pesos per year. China's maximum imports of silver never exceeded three million pesos in a year, so there was ample supply to accommodate Chinese demand. Nor is it true that China's exports of tea and silk declined during this period; on the contrary, exports of tea and silk reached an unprecedented high level in the early 1830s (Fig. 9). ${ }^{17}$ Chinese exports then levelled off until the dramatic surge to far higher levels that occurred in the 1850s.

Other recent estimates of the silver outflow by Chinese scholarsalthough higher than my figures-have largely downplayed the magnitude of the drain of silver in the first half of the nineteenth century. The economist He Liping, for example, has calculated that net silver exports averaged 1.86 million liang per year during the 22 years between 1817 and 1839, for a total net loss of 40.84 million liang (1523 metric tons) (He 2007: 70). He concludes, based on estimates of China's total silver stock c. 1800 that range from 600 million to 1.1 billion liang, that the net outflow of silver during this period amounted to only $3.6-6.7 \%$ of

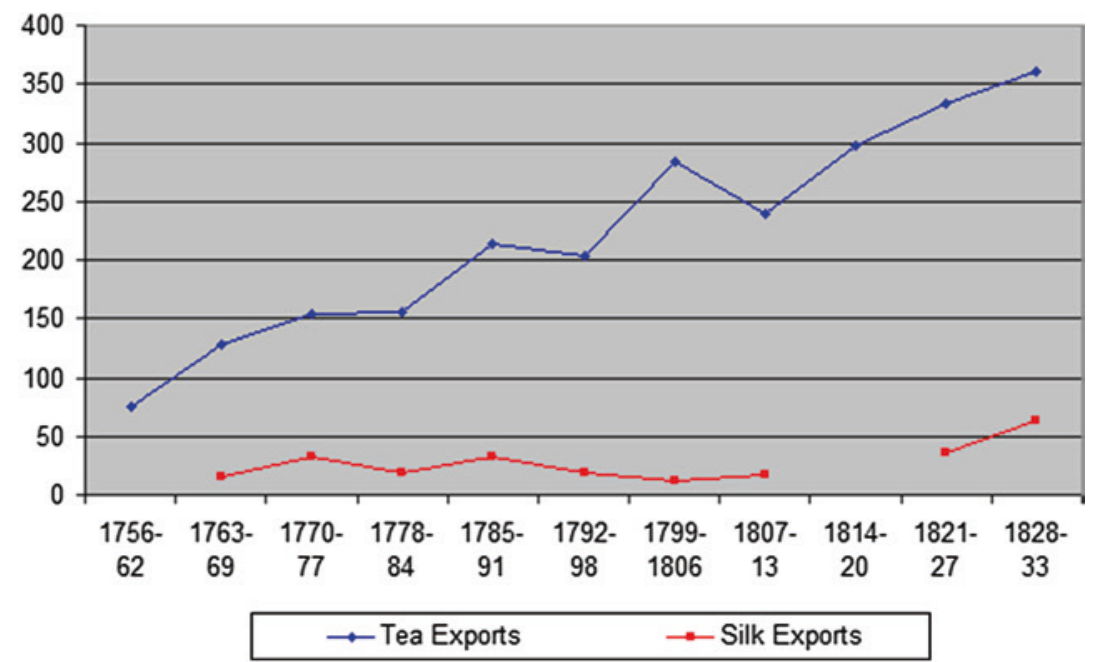

Fig. 9 Tea and silk exports, 1756-1833. (annual averages; tea exports in thousands of piculs; silk exports in hundreds of piculs): Silk data is incomplete and no silk data is available for 1756-1762 and 1814-1820. Source Dermigny 1964: 2, $549-553$ 
China's total silver stock. If we use instead Hamashita Takeshi's estimate of 1.67 billion yuan (equivalent to 1.16 billion liang) for China's total silver stock in the 1850 s, the net outflow of silver before 1839 based on He's figures would have been only 3.5\% (Hamashita 1984: 391). ${ }^{18}$ The stock of money is obviously relevant for understanding bullion movements because the significance of fluctuations of silver imports will depend on the size of the existing stock. From the perspective of stock demand, I fully concur with He's conclusion that this magnitude of silver export could not have caused the drastic effects commonly ascribed to it.

The principal evidence for a shortage of silver in China during the first half of the nineteenth century is the sharp appreciation of silver (relative to bronze coin) beginning in the mid-1830s (Fig. 10). Contemporary Chinese statesmen attributed the falling value of bronze coin to the widespread use of foreign silver pesos as a means of exchange and exhorted the court to halt the circulation of foreign coin. Undoubtedly the greater utility of a silver coin of standard weight and purity such as the Spanish peso contributed to the diminished value of bronze coin, but bronze coin also depreciated relative to uncoined sycee silver. Debasement of the bronze coin issued by the state-confirmed by numismatic evidence-encouraged widespread private minting of

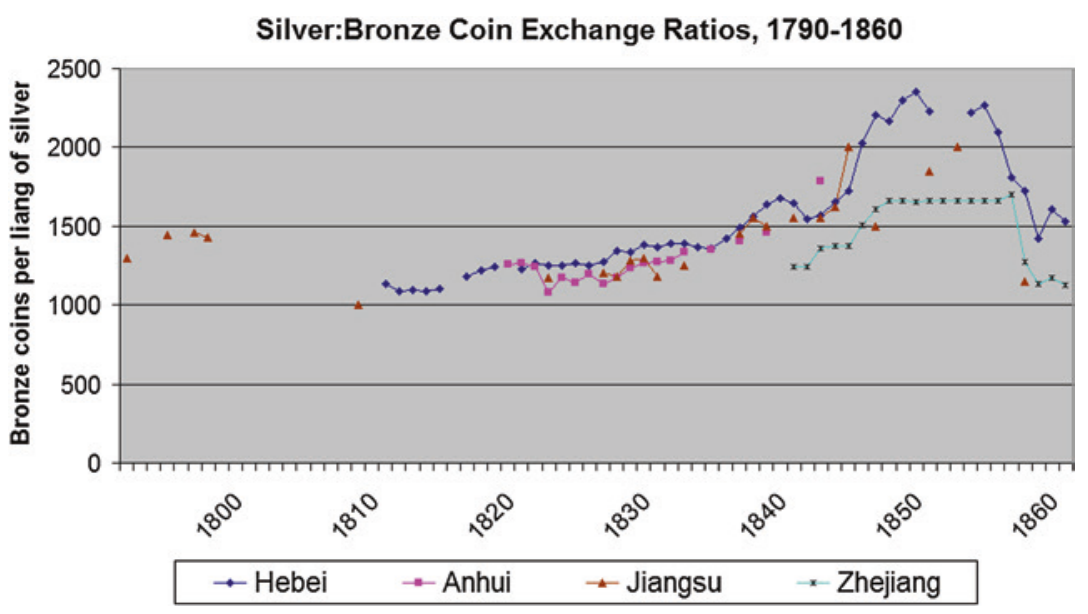

Fig. 10 Silver: Bronze coin exchange ratios, 1790-1860. Source von Glahn (2013: 55, Fig. 2.20) 
heavily adulterated coin (Burger 2015; Wang 2003: 196-199). Thus, the increasingly inferior quality of bronze coin contributed to its fall in value. Another new development that contributed to the depreciation of bronze coin was the growing issue of bronze coin-denominated paper notes (qianpiao) by the private banks (qianzhuang and yinhao) that began to proliferate from the end of the eighteenth century, especially in North China (Wang 2003: 180-184; von Glahn 2013: 55-57). ${ }^{19}$

Surprisingly, Fig. 10 reveals that the depreciation of bronze coin appears to have been significantly more severe in North China, traditionally a region more dependent on bronze coin, rather than in Jiangnan, where silver was in more common use and the Spanish peso coin (the Carolus dollar) had become widely employed as a means of exchange. Oscillations in the silver-bronze coin exchange ratios reflected the differential demand for each type of currency, and not simply a shortage of silver. As Kuroda Akinobu persuasively argues, the fragmentary structure of currency circulation in late imperial China and the high seasonality of monetary demand resulted in a disproportionate demand for means of payment, especially bronze coin, within local markets. In the Qing period this demand was increasingly satisfied by money substitutes such as qianpiao. In Kuroda's view, China suffered from shortages of bronze coin, not silver. Given the lack of integration between local-level and upper-level markets, the influx of foreign silver did not fundamentally alter the autonomy of local currency circuits (Kuroda 2000, 2008: 187-198).

In my view, a key feature of the Chinese monetary system throughout the entire imperial era has been endemic shortages of money. Since the establishment of the bronze coin monetary standard in the Qin and Han dynasties, the state was unable to supply sufficient quantities of low-value bronze currency to meet the needs for a means of exchange. This problem became increasingly acute during the late imperial era with the growing penetration of the market in all regions of the Empire. Even during the peak period of mint output in the late eleventh century, when the Northern Song dynasty minted over five billion coins per year, contemporaries complained of shortages of money severe enough to be called 'coin famines' (qianhuang). Over and over again, in Chinese history we see a strong preference for the more abundant currency. Thus, bronze coin tended to rise in value at times when the state minted large quantities of coin (in the Northern Song and the mid-Qing) and fall when mint output slackened (in the Southern Song and the Ming). 
The adoption of new monetary standards — such as the Song huizi paper money and the Carolus silver peso in the nineteenth century-above all was premised on having a sufficient supply of currency to meet the demand for currency. This demand preference contradicts the simplistic assumptions of the fairly crude versions of the quantity theory of exchange that all too often have been employed uncritically by historians. Moreover, the value of bronze coin hardly rose once silver began to flow into China in even greater quantities after 1855. On the contrary, according to the records of the Imperial Maritime Customs, the value of bronze coin remained below the average values of the 1820s for the rest of the century (Fig. 11).

We also find a parallel trend in the depreciation of coin relative to silver during the early nineteenth century in Vietnam, where the value of silver rose sharply in the late 1820 s, with another steep increase occurring in the 1840s (Fig. 12). Ironically, the appreciation of silver in Vietnam was mostly attributed to exports of silver to China (estimated at two million liang/lang per year in the 1830s) as well as the debasement of the Dai Viet kingdom's coinage, which from 1813 was minted from zinc rather than copper (Fujiwara 1960: 42-48). It is worth noting that the second quarter of the nineteenth century was a period of economic

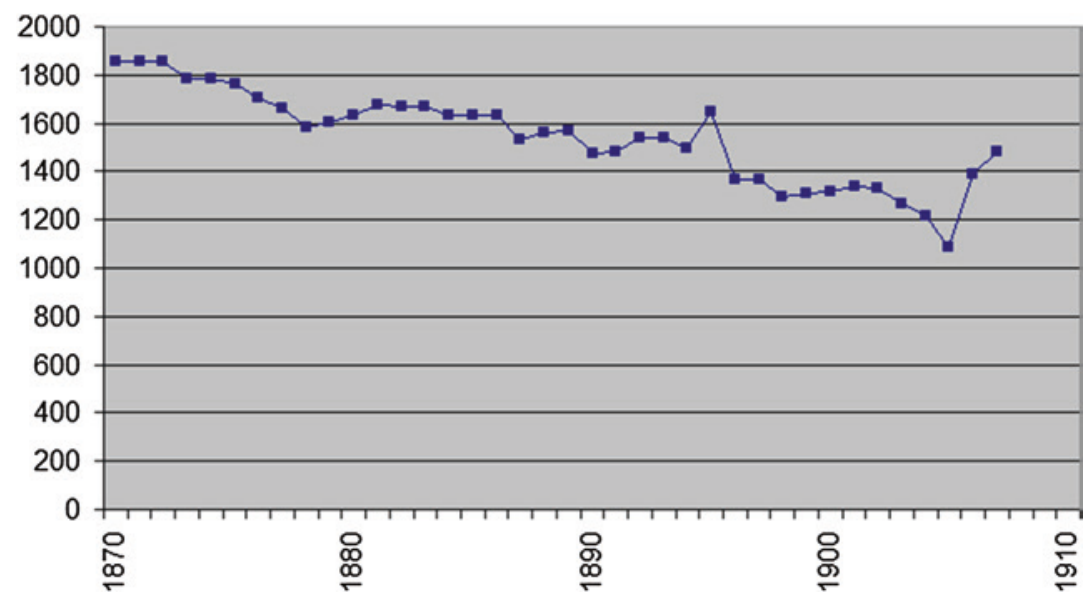

Fig. 11 Silver-Bronze coin exchange ratios, 1870-1906. Source Peng Xinwei (1965: 848) 


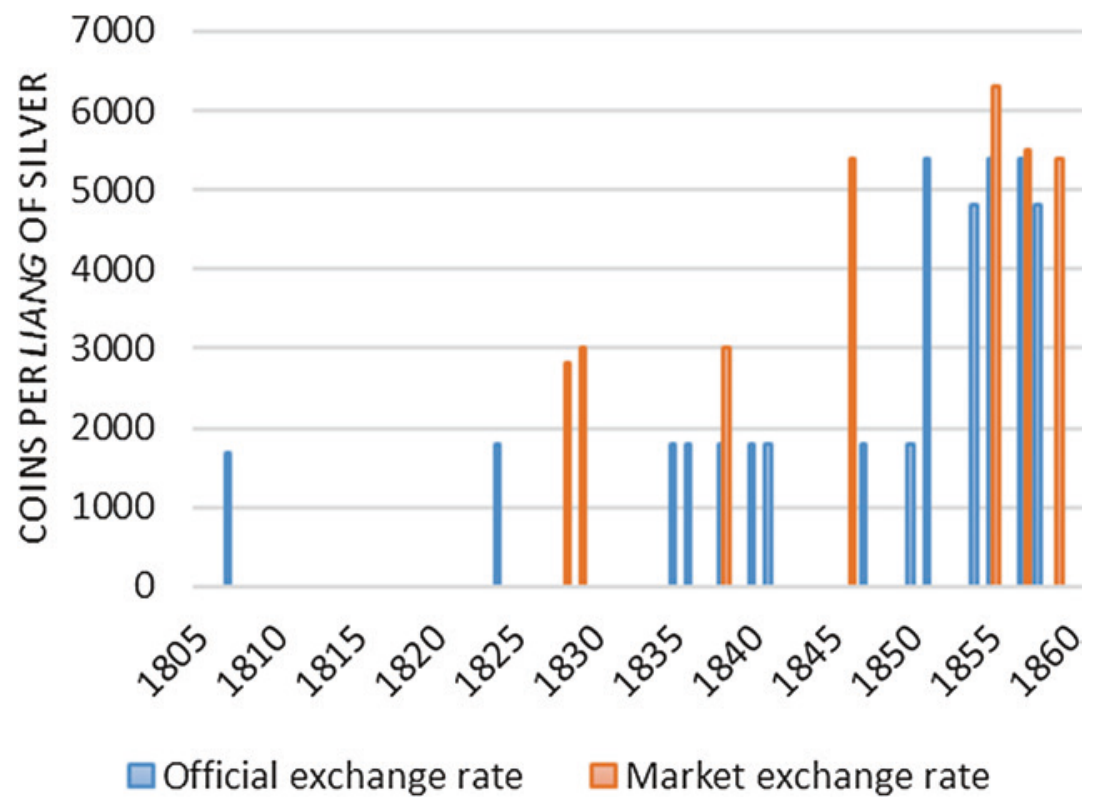

Fig. 12 Silver: Coin exchange ratios in Vietnam, 1807-1860. Source Taga 2015: 10-13, Tables 2 and 3

depression and deflation not only in China, but in other parts of Asia as well. ${ }^{20}$ In India, price deflation (including a steep erosion in the prices of export goods) persisted throughout these decades despite the growing infusions of silver from China. Economic distress was most acute during the crisis years of 1830-1833, when the East India Company repatriated enormous quantities of silver to Britain, but the malaise continued even after robust net inflows of silver returned from 1834 (Siddiqi 1983: 253-254, 1995, 16-25). ${ }^{21}$ In India, as in China, the causes of economic depression cannot be attributed to silver shortages alone.

The silver price deflation in China in the early nineteenth century thus cannot be correlated either with population trends or fluctuations in silver imports (or in foreign trade generally). There appears to be a closer correlation with the money supply. After the long secular increase of the eighteenth century, prices abruptly fell in the 1790s, when new infusions of money, both coin and silver, contracted sharply due to the White Lotus uprising and the curtailment of European overseas trade following 
the French Revolution and the outbreak of the Napoleonic Wars. But the correlation is inexact, especially during the period 1818-1827, when silver prices fell even as silver imports peaked. The deflationary trend that commenced c. 1815 cannot be explained by variations in the money supply. Moreover, the standard estimates of money supply fail to account for the spreading use of paper substitutes such as qianpiao and the 'silver notes' (yinpiao) that were widely used in South China. Li Longsheng has gone so far as to propose that the volume of silver notes in circulation (which he estimates at 61 million taels) fully replaced the net outflow of silver (62 million taels, by his estimate) during the period 1820-1851 ( $\mathrm{Li}$ 2010: 179-180, Table 3.20). However, in the absence of more explicit evidence for the volume of notes in circulation, this hypothesis remains speculative.

As the pronounced dip in grain prices in the 1790s indicates (and the outbreak of the White Lotus Rebellion confirmed), China's domestic economy was displaying signs of serious strain. We lack data to measure changes in output and trade with any precision, but reports from inland and maritime customs depots are revealing. Table 5 shows the revenues reported by the four largest customs depots. The data indicate that trade volume peaked in domestic commercial centres such as Huai'an (lynchpin of the Grand Canal, and the salt trade in particular), Suzhou (hub of the national rice market) and Jiujiang (a major Yangzi River port and gateway to the Middle Yangzi tea-producing regions) in the 1770s-1790s and declined thereafter. In contrast, maritime trade at Guangzhou soared in the late eighteenth century; beginning in 1802, the maritime customs revenue of Guangzhou surpassed

Table 5 Customs revenues, 1725-1831. (thousands of silver taels)

\begin{tabular}{llllllll}
\hline Huai'an Inland & \multicolumn{3}{l}{$\begin{array}{l}\text { Xupu (Suzhou) } \\
\text { Inland }\end{array}$} & & \multicolumn{2}{c}{ Jimjiang Inland } & \multicolumn{2}{c}{ Guangzhou Maritime } \\
\hline 1725 & 84 & 1727 & 353 & 1731 & 252 & 1727 & 91 \\
1736 & 484 & 1738 & 382 & 1739 & 352 & 1742 & 310 \\
1753 & 325 & 1753 & 495 & 1753 & 354 & 1753 & 515 \\
1773 & 557 & 1764 & 542 & 1776 & 662 & 1765 & 600 \\
1818 & 441 & 1791 & 583 & 1801 & 539 & 1804 & 1642 \\
1828 & 302 & 1818 & 427 & 1820 & 585 & 1812 & 1375 \\
1831 & 324 & 1831 & 391 & 1829 & 600 & 1831 & 1462 \\
\hline
\end{tabular}

Source Wu Chengming (2001: 271, Table 18) 
the total revenues of the three largest inland customs stations, testifying both to the vitality of overseas trade and the torpor into which domestic trade had descended. Customs revenues at Guangzhou and Jiujiang held relatively steady from the turn of the century up to the Opium War (although the Jiujiang receipts remained below their eighteenth-century peak). Customs revenue figures at Suzhou and Huai'an reveal a downward trend across the first half of the nineteenth century well below late eighteenth-century levels.

Although the economic expansion of the eighteenth century initially fostered a more integrated national market centred on Jiangnan, by the end of the century a strong centrifugal trend towards regionalization and rustification had emerged. Migration to the marginal agricultural regions of the interior arrested growth in labour productivity. Crop yields continued to improve in Jiangnan, but overall agricultural productivity probably declined. In North China, production of cotton and other non-food crops fell after 1750, reflecting a shift towards subsistence farming to meet the needs of the region's still rapidly growing population (Pomeranz 2000: 140-141). The proportion of the total population living in cities declined to about $5 \%$ in the mid-nineteenth century, less than half the urbanization rate of the Southern Song (Skinner 1977: 229). ${ }^{22}$ Jiangnan's share of the national population shrank from $14 \%$ in 1391 to $7.6 \%$ in $1776 .^{23}$

Jiangnan's pre-eminent role in the national economy diminished as well. For example, rural households in Hubei began to manufacture coarse cotton cloth which they exchanged for rice from the more productive agricultural regions of Hunan and Sichuan. Subsequently, Sichuan developed its own 'native cloth' (tubu) industry that marketed its products within Sichuan and in the outlying frontier provinces of Yunnan and Guizhou. The growth of rural industry in the interior came at the expense of core areas such as Jiangnan, which produced better-quality but more expensive cloth. As the market for Jiangnan textiles in the interior dried up, the flow of rice, timber and other raw materials down the Yangzi River ebbed (Yamamoto 1991; Pomeranz 2000: 242-249). This pattern of domestic 'import substitution' curtailed interregional trade (as we see in Table 5), resulting in greater regional autarky.

Jiangnan, China's most commercially developed region, was therefore particularly vulnerable to these structural changes in the Chinese economy. By the early nineteenth century, Jiangnan's economy bore little resemblance to the agrarian order that prevailed throughout most of 
China. According to Li Bozhong's reconstruction of the Hua-Lou local economy in the 1820s, manufacturing employed $56 \%$ of adult workers and generated $33 \%$ of total added value, in contrast to $27 \%$ and $31 \%$ respectively for agriculture. The Hua-Lou area had an urbanization rate as high as $40 \%$, and nearly $30 \%$ of its gross product (consisting almost entirely of cotton goods) was exported to external markets (Li 2010, 2013). But the cotton industry was by no means flourishing. According to Li's figures, cotton manufacture absorbed $43 \%$ of total employment in Hua-Lou, but generated only $9 \%$ of its aggregate product. Price data for the cotton industry is extremely fragmentary, but the few figures that do exist suggest a substantial decline compared to the eighteenth century. Data on Chinese cotton exports show that in the early 1830s, the price of cotton cloth (predominantly Songjiang 'nankeens') at Guangzhou had fallen 28\% compared to the average price of the 1810s (Wu 2001: 267). A treatise on Songjiang agriculture published in 1834 observed that the market for Songjiang cloth had been distressed for more than a decade, and poor cotton harvests since 1829 had made raw cotton prohibitively expensive. $^{24}$

\section{Conclusion}

Economic depression in early nineteenth-century China was marked by a sustained decline in silver prices beginning in c. 1815. The Daoguang Depression coincided with an ecological crisis: climatic disturbances, harvest failures and catastrophic floods, particularly during the period 1815-1835. Conventional explanations for China's economic troubles have emphasized either: (1) China's incorporation into a capitalist world economy on unfavourable terms, resulting in a massive drain of silver abroad, primarily to pay for opium imports; or (2) a Malthusian crisis of subsistence triggered by unsustainable population increases that overtaxed the productive capacity of the Chinese economy. Yet neither of these theses is satisfactory.

In the first place, the onset of economic depression pre-dated the reversal in the flow of silver bullion. As Li Bozhong has observed, complaints of economic distress and widespread impoverishment of rich and poor alike were already being aired by 1820 , well before the outflow of silver and bronze coin depreciation had become severe ( $\mathrm{Li} 2007$ : 173-178). Moreover, any assessment of the impact of silver flows on the Chinese economy must consider questions of demand as well as supply. 
As Kishimoto Mio has shown, the penetration of foreign silver as shown by the adoption of the Carolus peso as a monetary standard varied extensively by region, and even by type of transaction (Kishimoto 2011: 13-17). For example, in Jiangnan, the Carolus peso was widely used as the common currency of trade and finance by the beginning of the nineteenth century, yet land sale contracts continued to be denominated in bronze coin well into the nineteenth century. The complexity of China's domestic monetary system at this time-which included Carolus pesos, copper and silver notes, and bronze coin as well as bullion silver-is still not sufficiently well understood. Given the present state of knowledge, we should beware any theories that treat the Chinese monetary systemor, for that matter, the Chinese economy-as an undifferentiated whole.

The new evidence for a Malthusian crisis from recent research-falling per capita GDP and real wages - is encumbered by methodological problems and questionable theoretical assumptions. The reversal of price trends in c. 1815-resulting in steep deflation in silver prices, but a steady level in relative prices-and the continuous population expansion down to the outbreak of the Taiping Rebellion belie a Malthusian narrative. Of course, given the massive scale of the Chinese Empire, regional variations were undoubtedly significant. The decline of cotton cloth manufacture in Jiangnan during the second quarter of the nineteenth century was related to structural and long-term conjunctural shifts in China's domestic economy. The concentration of population growth in poorer regions in western China and the increasing rustification of handicraft production had adverse effects on urban manufacture in regions such as Jiangnan, which could no longer compete with cheaper cotton goods produced in the interior regions.

The economic depression in early nineteenth-century China should be seen in the context of a long-standing pattern of conjunctural oscillation of economic expansion and contraction typical of advanced pre-modern economies. In the classic formulation of François Simiand, a long wave of economic expansion-the A-phase of population growth, expanding output and rising prices-was inevitably followed by an equally long B-phase of high mortality, deflation and stagnant output (Simiand 1932). Jack Goldstone has argued that the A-phase of commercial growth and economic prosperity that germinated across Eurasia in the early sixteenth century ultimately culminated in the economic distress, social conflicts and political crises that erupted in Ming China, Western Europe and the Ottoman Empire in the mid-seventeenth century. The 
subsequent B-phase of economic contraction lasted until the early eighteenth century before the Chinese and European economies regained momentum, inaugurating a new A-phase (Goldstone 1991). In my view, although we can find some parallels in the cyclical trends of growth and decline in China and Europe in the period 1500-1800, there were crucial differences as well. ${ }^{25}$ In the case of China, the long A-phase that lasted from the 1690s down to the 1790s did not end in a demographic collapse, but rather a precarious equilibrium. It is quite possible that eighteenth-century China experienced an 'industrious revolution' not unlike that hypothesized for contemporary Japan and Europe, in which population expansion was accompanied by the intensification of work and increased non-agricultural production in the countryside that, together with the development of horizontal exchange within local and regional markets, led to economic specialization and productivity gains equalling or exceeding demographic growth. ${ }^{26}$ Despite the apparent synchronicity of the Daoguang Depression and the B-phase of deflation and economic contraction in Europe during the period 1817-1850, fundamental differences between the economies of China and Europe had emerged by this time. ${ }^{27}$

In addition, the role of silver imports in the Chinese economy had changed since the 'Silver Century' of 1550-1650. The primacy of silver - a cardinal feature of the A-phase of 1500-1650- became attenuated as bronze coin displaced silver bullion as the monetary standard in many local markets in the eighteenth century. Moreover, the economics of the silver trade had changed dramatically, as the arbitrage profits that orchestrated the global movements of silver during the 'Silver Century' vanished. Just as the causes of the Daoguang Depression are to be found in China's domestic economic conditions rather than the global economy, the reduced demand for money (silver and bronze coin alike) during these decades was a symptom, not the cause, of this economic distress.

\section{Notes}

1. For an introduction to the revisionist approach and basic arguments of the 'California School', see Goldstone (2000).

2. For an incisive argument asserting the fallacy of GDP as a measure of economic productivity in pre-modern societies, see Du and Jin (2011). GDP is intended to measure all goods, labour and services that entered the marketplace, but much of the gross product of pre-modern societies was 
not marketed. Conversion of values into universal measures for purposes of comparison such as 1990 US dollars also requires a standard index for prices (usually gold, which had no monetary function in China) that may not actually reflect real market values. On the technical problems of price calculations for GDP estimates, see Peng Kaixiang (2011).

3 . For more details on the deficiencies of Liu's methodology, see my review of his book in T'oung Pao 102.4-5 (2016): 566-70.

4. The authors conclude that their findings confirm Huang's involution thesis, but their model does not provide an adequate test of that thesis.

5. The authors calculate that China's per capita GDP in the eighteenth century was far below the levels of Spain and Italy as well.

6. The 1820s were a period of economic torpor, if not depression, in both regions.

7. Debin Ma (2008) calculates that per capita GDP in Jiangsu-Zhejiang in the early twentieth century was roughly 50 per cent higher than the average for China as a whole. He also points out that per capita tax revenue (which perhaps can be taken as a rough proxy for income) was also $50 \%$ higher in Jiangsu-Zhejiang during the eighteenth century.

8. Allen concludes that the golden age for Jiangnan farming/weaving families came in the early seventeenth century, but of course his study skips over the intervening two centuries. If one substitutes the much higher cotton cloth prices that prevailed in the late eighteenth century in place of the extremely depressed prices of the 1820s, I suspect that the golden age continued down to 1800 irrespective of population growth.

9. Xu Dixin and Wu Chengming estimated that only $1-2 \%$ of the Ming population were wage labourers.

10. For Jiangnan prices, see Yeh-chien Wang (1992); for Guangdong, see Marks and Chen (1995). Wheat prices in Zhili (Lillian Li 1992) and rice prices in Hunan (Wong and Perdue 1992) rose very gradually from 1740 to 1790 .

11. For further data on grain prices in the north which show the same trends, see Lillian Li (2007: 196-220) and Lee and Campbell (1997: 27-39).

12. This is also the conclusion of Peng Kaixiang (2006).

13. From 1738 to 1810 , Yunnan copper mines produced an average of 6000 tons of copper annually, reaching a peak of 9000 tons in 1764 (Vogel 1987: 32-33).

14. On the return to a bronze coin monetary standard in Jiangnan in the mideighteenth century, see Kuroda (1987); Kishimoto (1997: 353-363).

15. Needless to say, Bao's hyperbolic figures are hardly credible.

16. For more detailed critiques of Lin's analysis, see Irigoin (2009) and von Glahn (2013: 49-58). 
17. As Wang Jingyu (2006: 497) observes, the appreciation of silver in China-at a time when silver was depreciating in the London marketshould have been favourable to Chinese exports.

18. Hamashita's figure, based on an 1850 report from the British governor in Hong Kong, seems preferable to the figures cited by He.

19. Provincial officials roundly blamed the excess of qianpiao notes for contributing to the depreciation of bronze coin.

20. A preliminary assessment of the common trend of deflation and economic distress in Southeast Asia during the first half of the nineteenth century was presented in Ōhashi (2015).

21. For the data on silver imports and exports to India, see Chaudhuri (1966: 358-359, Tables 4 and 5). Although Indian opium and cotton exports surged during 1830-1833, the East India Company delivered its silver bullion proceeds from China directly to Britain rather than to India. See Bowen (2010: 473).

22. Skinner estimated China's urbanization rate in 1843 at $5.1 \%$.

23. For population data for the eight core prefectures of Jiangnan for 1391 and 1776, see respectively Li Bozhong (2003: 142, Table 5.3) and Cao Shuji (2000: 87-88, Table 3-5, 113, Table 3-15).

24. Cited in Li Bozhong (2010: 492).

25. For a detailed analysis, see von Glahn (2003).

26. On the concept of 'industrious revolution'-which has been applied in somewhat different ways to eighteenth-century Japan and Western Europe, see Hayami (1979) and de Vries (2008). The studies of Pomeranz (2000) and Li Bozhong (2010) implicitly suggest that just such an 'industrious revolution' occurred in Qing China.

27. On the dating of a B-phase of economic contraction in Europe to 18171850, see Vilar (1974: 397-399).

\section{REFERENCES}

Allen, Robert C. 2009. Agricultural Productivity and Rural Incomes in England and the Yangtze Delta, c. 1620-c. 1820. Economic History Review 62 (3): 525-550.

Allen, Robert C., Jean-Pascal Bassino, Debin Ma, Christine Moll-Murata, and Jan Luiten Van Zanden. 2011. Wages, Prices, and Living Standards in China, 1738-1925: In Comparison with Europe, Japan, and India. Economic History Review 64, supplement 1: 8-38.

Atwell, William S. 1986. Some Observations on the 'Seventeenth-Century Crisis' in China and Japan. Journal of Asian Studies 45 (2): 223-244.

. 2006. Another Look at Silver Imports into China, ca. 1635-1644. Journal of World History 16 (4): 467-489. 
Bowen, H.V. 2010. Bullion for Trade, War, and Debt Relief: British Movements of Silver to, around, and from Asia, 1760-1833. Modern Asian Studies 44 (3): $445-475$.

Broadberry, Stephen, Hanhui Guan, and David Daokui Li. 2017. China, Europe, and the Great Divergence: A Study in Historical National Accounting, 9801850. In: www.lse.ac.uk/economicHistory/pdf/Broadberry/China8.pdf.

Burger, Werner. 2015. Silver is Expensive, Cash is Cheap: Official and Private Cash Forgeries as the Main Cause for the 19th Century Monetary Turmoil. In: Money in Asia (1200-1900): Small Currencies in Social and Political Contexts, eds. Jane Kate Leonard and Ulrich Theobald, 141-154. Leiden: Brill.

Cao, Shuji 曹树基. 2000. Zhongguo renkou shi: Qing shiqi 中国人口史, vol. 5, 清 时期. Shanghai: Fudan daxue chubanshe.

Chao, Kang. 1988. Man \& Land in Chinese History: An Economic Analysis. Stanford: Stanford University Press.

Chaudhuri, K.N. 1966. India's Foreign Trade and the Cessation of the East India Company's Trading Activities, 1828-40. Economic History Review 19 (2): 346-363.

Chen, Chunsheng 陳春聲. 2005. Shichang jizhi yu shehui bianqian: 18 shji Guangdong mijia fenxi 市場機制與社會變遷:18世紀廣東米價分析. 2nd ed. Taipei: Daoxiang chubanshe.

Dermigny, Louis. 1964. La Chine et l'occident: le commerce à Canton au XVIII siècle. Paris: S.E.V.P.E.N.

De Vries, Jan. 2008. The Industrious Revolution: Consumer Behavior and the Household Economy, 1650 to the Present Day. Cambridge: Cambridge University Press.

Du, Xuncheng 杜恂诚 and Li Jin 李晋. 2011. Zhongguo jingji shi 'GDP' yanjiu zhi wuqu 中国经济史 “GDP” 研究之误区. Xueshu yuekan 学术月刊 43 (10): $74-81$.

Dunstan, Helen. 2005. State or Merchant? Political Economy and Political Process in 1740s China. Cambridge: Harvard University Asia Center.

Goldstone, Jack A. 1991. The Causes of Long Waves in Early Modern Economic History. Research on Economic History, supplement 6: 51-92.

- 2000. The Rise of the West-or Not? A Revision to Socio-Economic History. Sociological Theory 18 (2): 175-194.

Fujiwara, Riichirō 藤原利一郎. 1960. Genchō shita ni okeru kinginka no mondai 阮朝下における金銀価の問題. Shiso 史空17-18: 35-50.

Hamashita, Takeshi. 1984. Foreign Trade Finance in China, 1810-1850. In: State and Society in China: Japanese Perspectives on Ming-Qing Social and Economic History, eds. Linda Grove and Christian Daniels, 387-435. Tokyo: University of Tokyo Press. 
Hayami, Akira 速水融. 1979. Kinsei Nihon no keizai hatten to 'Industrious Revolution'。近世日本の経済発展と 'Industrious Revolution'. In: Kindai ikōki no Nibon keizai 近代移行期の日本経済, eds. Shinbō Hiroshi 新保博 and Yasuba Yasukichi 安場保吉, 3-14. Tokyo: Nihon keizai shimbunsha.

$\mathrm{He}$, Liping 贺力平. 2007. Yapian maoyi yu baiyin wailiu guanxi zhi zai jiantaojianlun guonei huobi gongji yu duiwai maoyi guanxide lishi yanbian 鸦片贸 易与白银外流关系之再检讨一兼论国内货币供给与对外贸易关系的历史演变. Shehui kexue zhanxian 社会科学战线 2007. 1: 63-80.

Huang, Philip C.C. 1990. The Peasant Family and Rural Development in the Yangzi Delta, 1350-1988. Stanford: Stanford University Press.

Irigoin, Alejandra. 2009. The End of a Silver Era: The Consequences of the Breakdown of the Spanish Peso Standard in China and the United States, 1780s-1850s. Journal of World History 20 (2): 207-243.

Kishimoto, Mio 岸本美緒. 1997. Shindai Chügoku no bukka to keizai hendō 清代 中国の物価と経済变動. Tokyo: Kembun shuppan.

—. 2009. New Studies on Statecraft in Mid- and Late-Qing: Qing Intellectuals and their Debates on Economic Policies. International Journal of Asian Studies 6 (1): 93-95.

- 2011. Foreign Silver and China's Domestic Economy. Presented at the Third European Congress on World and Global History. London, 14-17 April, 2011.

Kuroda, Akinobu 黒田明信. 1987. Kenryū no senki 乾隆の銭貴. Tōyōshi kenkyū 東洋史研究 45 (5): 692-723.

- 2000. Another Monetary Economy: The Case of Traditional China. In: Asia-Pacific Dynamism, 1500-2000, eds. A.J.H. Lathan and Heita Kawakatsu, 187-98. London: Routledge.

- 2008. Concurrent but Non-Integrable Currency Circuits: Complementary Relationships among Monies in Modern China and Other Regions. Financial History Review 15 (1): 17-36.

Lee, James Z., and Cameron Campbell. 1997. Fate and Fortune in Rural China: Social Organization and Population Behavior in Liaoning, 1774-1873. Cambridge: Cambridge University Press.

Li, Bozhong 李伯重. 2003. Was There a 'Fourteenth-Century Turning Point? Population, Land, Technology, and Farm Management. In: The Song-YuanMing Transition in Chinese History, eds. Paul Jakov Smith and Richard von Glahn, 135-175. Cambridge: Harvard University Asia Center.

- 2007. Daoguang xiaotiao yu guiwei dashui 道光萧条与癸未大水. Shehui kexue 社会科学 2007. 6: 173-178.

- 2010. Zhongguode zaoqi jindai jingji: 1820 niandai Huating-Louxian diqu GDP yanjiu 中国的早期近代经济:1820年代华亭一娄县地区 GDP 研究. Beijing: Zhonghua shuju. 
2013. An Early Modern Economy in China: A Study of the GDP of the Huating-Lou Area, 1823-1829. In: The Economic History of Lower Yangzi Delta in Late Imperial China: Connecting Money, Markets, \& Institutions, ed. Billy K.L. So, 133-145. London: Routledge.

Li, Bozhong, and Jan Luiten Van Zanden. 2012. Before the Great Divergence? Comparing the Yangzi Delta and the Netherlands in the Beginning of the Nineteenth Century. Journal of Economic History 72 (4): 956-989.

Li, Lillian M. 1992. Grain Prices in Zhili Province, 1736-1911: A Preliminary Study. In: Chinese History in Economic Perspective, eds. Thomas G. Rawski and Lillian M. Li, 69-99. Berkeley: University of California Press.

- 2007. Fighting Famine in North China: State, Market, and Environmental Decline, 1690s-1990s. Stanford: Stanford University Press.

Li, Longsheng 李隆生. 2010. Qingdaide guoji maoyi: baiyin liuru, huobi weiji he Wan Qing gongyehua. 清代的國際貿易: 白銀流入,貨幣危機和晚清工業化. Taipei: Xiuwei zixun keji.

Lin, Man-houng. 2006. China Upside Down: Currency, Society, and Ideologies, 1808-1856. Cambridge: Harvard University Asia Center.

- 2011. Latin America Silver and Early Nineteenth-century China. Presented at the Third European Congress for World and Global History. London, April 14-17, 2011.

Liu, William Guanglin. 2015. The Chinese Market Economy, 1000-1500. Albany: State University of New York Press.

Liu Ti 刘逖. 2009. “1600-1840 nian Zhongguo guonei shengchan zongzhi gusuan” 1600-1840 年中国国内生产总值估算. Jingji yanjiu 经济研究 2009. 10: 144-155.

Ma, Debin. 2008. Economic Growth in the Lower Yangzi Region of China in 1911-1937: A Quantitative and Historical Analysis. Journal of Economic History 68 (2): 355-392.

Maddison, Angus. 2001. The World Economy: A Millennial Perspective. Paris: OECD Publications.

- 2007. Chinese Economic Performance in the Long Run, 960-2030 AD. Rev. ed. Paris: OECD Publications.

Mann Jones, Susan, and Philip Kuhn. 1978. Dynastic Decline and the Roots of Rebellion. In: The Cambridge History of China, vol. 10, Late Ch'ing, 18001911, ed. John K. Fairbank, 1: 107-162. Cambridge: Cambridge University Press.

Marks, Robert B. 2002. The Origins of the Modern World: A Global and Ecological Narrative. Lanham: Rowman \& Littlefield.

Marks, Robert B., and Chunsheng Chen. 1995. Price Inflation and its Social, Economic, and Climatic Context in Guangdong Province, 1707-1800. T'oung Pao 81 (1-3): 109-152. 
Moulder, Frances V. 1977. Japan, China, and the Modern World Economy: Toward a Reinterpretation of East Asian Development ca. 1600 to ca. 1918. Cambridge: Cambridge University Press.

Ōhashi, Atsuko. 2015. An Era of Deflation and Southeast Asia: The First Half of the 19th Century. Presented at the XVII World Economic History Congress. Kyoto, 3-7 August, 2015.

Peng, Kaixiang 彭凯翔. 2006. Qingdai yilaide liangjia: lishixuede jieshi yu zaijieshi 清代以来的粮价:历史学的解释与再解释. Shanghai: Shanghai renmin chubanshe.

- 2011. Lishi GDP gusuan zhongde jijia wenti chuyi 历史 GDP 估算中 的计价问题刍议. Zhongguo jingji shi yanjiu 中国经济史研究 2011. 4: 53-60.

Peng, Xinwei 彭信威. 1965. Zhongguo huobi shi 中國貨幣史. 2nd ed. Shanghai: Shanghai renmin chubanshe.

Peng, Zeyi 彭泽益. 1983. Shijiu shiji houbanqide Zhongguo caizheng yu jingji 十 九世纪后半期的中国财政与经济. Beijing: Renmin chubanshe.

Pomeranz, K. 2000. The Great Divergence: China, Europe, and the Making of the Modern World Economy. Princeton: Princeton University Press.

- 2008. Chinese Development in Long-Run Perspective. Proceedings of the American Philosophical Society 152 (1): 83-100.

Rowe, William T. 2010. Money, Economy, and Polity in the Daoguang-Era Paper Currency Debates. Late Imperial China 31 (2): 69-96.

Shi, Zhihong, Ni Yuping, and Bas van Leeuwen. 2014. Chinese National Income, ca. 1661-1933. Centre for Global Economic History (Utrecht University). Working Paper Series, no. 62. http://www.cgeh.nl/sites/ default/files/WorkingPapers/CGEHWP62_ShiXuyiNiVanLeeuwen.pdf.

Siddiqi, Asiya. 1983. Money and Prices in the Earlier Stages of Empire: India and Britain, 1760-1840. Indian Economic and Social History Review 18 (3-4): 231-262.

- 1995. Introduction. Trade and Finance in Colonial India, 1750-1860. New Delhi: Oxford University Press.

Simiand, François. 1932. Recherches anciennes et nouvelles sur le mouvement general des prix du $16^{e}$ au $19^{e}$ siècle. Paris: Domat Montchrestien.

Skinner, G. William. 1977. Regional Urbanization in Nineteenth-Century China. In: The City in Late Imperial China, ed. G. William Skinner, 212-49. Stanford: Stanford University Press.

Taga, Yoshihiro. 2015. The Development of the Silver Economy in Nineteenth Century Vietnam. Presented at XVII World Economic History Congress. Kyoto, 3-7 August, 2015.

Vilar, Pierre. 1974. Or et monnaie dans l'histoire. Paris: Flammarion.

Vogel, Hans Ulrich. 1987. Chinese Central Monetary Policy, 1644-1800. Late Imperial China 8 (2): 1-52. 
1644-1800. Unpublished manuscript.

von Glahn, Richard. 2003. Money-Use in China and Changing Patterns of Global Trade in Monetary Metals, 1500-1800. In: Global Connections and Monetary History, 1470-1800, eds. Dennis O. Flynn et al. 187-205. UK: Ashgate Press.

- 2013. Cycles of Silver in Chinese Monetary History. In: The Economic History of Lower Yangzi Delta in Late Imperial China: Connecting Money, Markets, \& Institutions, ed. Billy K.L. So, 17-71. London: Routledge.

- 2016. Review of William Guanglin Liu, The Chinese Market Economy. Toung Pao 102 (4-5): 566-570.

Wang, Jingyu 汪敬虞. 2006. Guanyu yapian zhanzhenghou shinianjian yingui qianjian yingxiangxia Zhongguo dui waimao wentide shangque. 关于鸦片战 争后十年间银贵钱贱影响下中国对外贸问题的商榷. In: Zhongguo shehui jingji shi luncong: Wu Chengming jiaoshou jiushi huadan jinian wenji 中国社会 经济史论从: 吴承明教授九十华诞纪念文集，ed. Fang, Xing 方行，492-506. Beijing: Xinhua shudian.

Wang, Yeh-chien 王業鍵. 1992. Secular Trends of Rice Prices in the Yangzi Delta, 1638-1935. In: Chinese History in Economic Perspective, eds. Thomas G. Rawski and Lillian M. Li, 35-68. Berkeley: University of California Press.

—. 1996. Shijiu shiji qianqi wujia xialuo yu Taiping tianguo geming 十九世 紀前期物價下落與太平天國革命. In: Shibian, qunti, yu geren: diyijie quanguo lishixue xueshu taolunhui lunwenji 世變,群體,與個人:第一屆全國歷史學學術 討論會論文集, 259-284. Taipei: Taida lishixi.

. 2003. Zhongguo jindai huobi yu yinhangde yanjin (1644-1937) 中國近 代貨幣與銀行的演進. Qingdai jingji shi lunwenji 清代經濟史論文集, 161-274. Taipei: Daoxiang chubanshe.

Will, Pierre-Étienne. 1994. Développement quantitatif et développement qualitatif en Chine à la fin de l'époque impériale. Annales: Histoire, Sciences Sociales 49 (4): 863-902.

Wong, R. Bin and Peter Perdue. 1992. Grain Markets and Food Supplies in Eighteenth-Century Hunan. In: Chinese History in Economic Perspective, eds. Thomas G. Rawski and Lillian M. Li, 126-144. Berkeley: University of California Press.

Wu, Chengming 吴承明. 2001. Shiba yu shijiu shiji shangyede Zhongguo shichang 18 与 19 世纪上叶的中国市场. Zhongguode xiandaibua: shichang yu shehui 中国的现代化: 市场与社会, 238-288. Beijing: Sanlian shudian.

Xu, Dixin, and Wu Chengming. 2000. Chinese Capitalism, 1522-1840. London: Macmillan.

Yamamoto, Susumu 山本進. 1991. Shindai Shisen no chiiki keizai: inyū daitai mengyō no keisei to Ha-ken gagyō 清代四川の地域経済:移入代替棉業の形 成と巴県牙行. Shigaku zasshi 史学雑誌 100 (12): 2005-2035. 
Open Access This chapter is licensed under the terms of the Creative Commons Attribution 4.0 International License (http://creativecommons.org/licenses/ by $/ 4.0 /$ ), which permits use, sharing, adaptation, distribution and reproduction in any medium or format, as long as you give appropriate credit to the original author(s) and the source, provide a link to the Creative Commons license and indicate if changes were made.

The images or other third party material in this chapter are included in the chapter's Creative Commons license, unless indicated otherwise in a credit line to the material. If material is not included in the chapter's Creative Commons license and your intended use is not permitted by statutory regulation or exceeds the permitted use, you will need to obtain permission directly from the copyright holder.

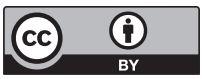

